\title{
Two-Level Games Theory in Panama-Taiwan Diplomatic Relations
}

\author{
Hafiyer Al Halim THA ${ }^{1}$ \\ ${ }^{1}$ University Of Indonesia \\ ${ }^{*}$ Corresponding author. Email: tulvahafiveralhalim@gmail.com
}

\begin{abstract}
On June 13, 2017, Taiwan faced shocking news. Panama announced abandoning diplomatic ties with Taiwan. On the same day, Panama also announced that it had officially established diplomatic relations with China. Taiwan responded with their disappointment in Panama for ending their long-time good relations. This raises questions about why Panama unilaterally broke diplomatic relations with Taiwan and turned to China, even though the two countries had had good relations for more than 100 years. This study describes the variables associated with the theory of two-level games by Robert Putnam. From the author's analysis, domestic and international level variables have the same size effect in achieving a win-set, which means termination of diplomatic relations. China succeeded in winning negotiations at the international level with strategic thinking that could benefit Panama in many aspects. Likewise, domestically, economic and historical factors were a burdensome reason for this foreign policy consideration.
\end{abstract}

Keywords: Panama, Taiwan, China, United States, Foreign Policy, two-level games

\section{PANAMA-TAIWAN RELATIONS}

In its history, Panama established diplomatic relations with China on January 16, 1910 (the Qing Dynasty era). When the Chinese Xinhai Revolution (1911-1912) changed the empire into a republic, Panama established diplomatic relations with the Republic of China (Taiwan) on January 2, 1912 (Staff Writer Taipei Times 2017). After the 1949 Communist Revolution, which forced the Chiang KaiShek nationalist camp to migrate to Formosa Island and establish the new Republic of China, Panama still maintained diplomatic relations with the Republic of China. Until the Mainland's Chinese government proclaimed the "One China Policy" in the 1970s, Panama still chose to maintain diplomatic relations with Taiwan (Staff Writer Taipei Times 2017). Since then, Panama's relations with Taiwan had gone very well.

As a developing country with the best economic growth rate in Latin America, Panama was a strategic ally for Taiwan's interests in the American continent and in international politics. Therefore, Taiwan actively established cooperative relations with Panama, covering investment and loans, technical assistance, and special technical missions for core projects such as education, infrastructure, agriculture, and fisheries (Esteban 2008). In 2003, Panama and Taiwan signed a free trade agreement (FTA). Data from the Taiwan Customs and Excise Directorate in 2006 showed that Panama's exports to Taiwan reached $26.4 \%$ (12.4\% higher than Panama's total exports to China) (Huang, Kwei-Bo in Schubert \& Gunter 2016). Relations between Taiwan and Panama were strengthened when Taiwan's Vice President Lu Hsiu Lien made a friendly visit to Panama in 2007. But the good, cooperative relations established between Taiwan and Panama changed immediately when official announcement of the termination policy was made by Panamanian President Juan Carlos Varela in a national television broadcast on June 13, 2017 (Wadrianto 2017). Then, in addition to announcing termination of diplomatic relations with Taiwan, President Varela also confirmed that from that day, his country had officially established diplomatic relations with China. The policy adopted by Varela was officially approved and became a unilateral policy, implemented without any communication with countries related to Taiwan.

This Panamanian foreign policy is interesting because the termination of diplomatic relations surprised the Taiwanese after their history of very close relations with Panama since the 1970s. The Taiwanese government deeply regrets and condemns Panama's policy (Ministry of Foreign Affairs ROC 2017). Directly, Taiwan severed diplomatic relations with 
Panama. This immediate response on June 13 upheld the nation's sovereignty and dignity. Taiwan closed its embassy in Panama, withdrew its technical mission, and ended all bilateral cooperation and aid programs. However, this policy did not undermine Taiwan. Taiwan continues to strive to face challenges. Furthermore, Taiwan will work harder in its dedication to protect its national interests and the welfare of its people.

\section{THE THEORY OF TWO-LEVEL GAMES}

International relations studies explain interaction between domestic and international actors. In fact, domestic politics and international relations are often linked. Even in determining a country's foreign policy, the government does not determine its attitude based solely on an outward (international) view, but also on an inward (domestic) view. Foreign policy results from competition and negotiations between the government and various domestic actors in pursuing their interests. On the other hand, international pressure is also an important factor in foreign policymaking. Similarly, the theory of two-level games put forward by Robert Putnam explains interaction between influences of domestic actors, such as parliaments, NGOs, and/or domestic groups, and international factors, such as the international system and/or division of world power.

In two-level game theory, a decision maker (head of government or state) must be able to maintain peace at both the domestic and international levels and also be able to win both parties (Putnam 1988). This theory focuses on interactions that occur between two playing fields, especially in the process of ratification. At the national level, domestic actors or groups pursue their interests by encouraging governments to make policy benefiting them, and politicians seek power by building coalitions with groups. Thus, at the international level, domestic governments strive to maximize their ability, so they can minimize consequences affecting foreign development but also address domestic pressures. Domestic pressure becomes important in this case, because without domestic accord, international pressure would not produce an agreement. This result is called a "win-set."

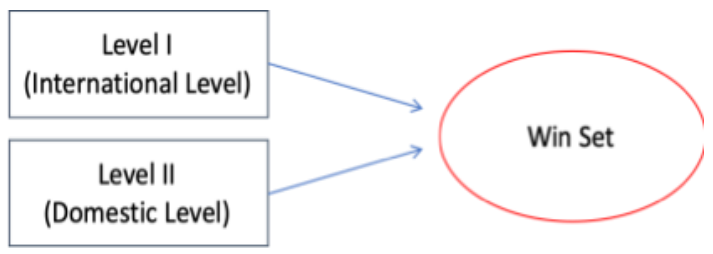

Figure 1 Two-Level Games Theory by Robert Putnam (Source: Robert Putnam 1988)
Win-set is the level of agreement or treaty at the second level (i.e., the domestic level) for successful negotiations at the first level (i.e., the international level). This means that the greater the domestic agreement, the greater the win-set and the greater the negotiations at the first level in achieving success. Conversely, the smaller the win-set, the greater the risk of negotiations being damaged. The win-set size depends on 1) distribution of power, preferences, and possible coalitions between components at the domestic level (Level II); 2) political institutions at the domestic level (Level II); and 3) various negotiator strategies at the international level (Level I). Using this theory, this paper describes possible variables affecting Panama's diplomatic termination in 2017 of favorable foreign policy with Taiwan.

\section{TWO-LEVEL GAMES IN PANAMA'S FOREIGN POLICY}

Based on Putnam's theory above, two factors are generally the reference for Panama's decision-making at international and domestic levels. Furthermore, the outcome of the two levels of consideration and negotiation is called a "win-set," which in this case, is Panama's diplomatic termination of Taiwan in 2017. To understand the form of this policy, this research first describes international level (Level I) Panama-China negotiation. Panama-Taiwan negotiation is not explained here because this policy was unilaterally made by Panama when it switched to China. Secondly, Panama's domestic actor negotiation, at the domestic level (Level II) continued with the "win-set," is described.

\subsection{Panama-China Negotiations (Level I)}

For years, China has pursued good relations with Latin American leaders in order to end recognition of Taiwan over Mainland China. China's expanding engagement with Latin America started in 2004, during the five-nation visit by Chinese President $\mathrm{Hu}$ Jintao in conjunction with the Asia-Pacific Economic Cooperation Forum (APEC) summit in Santiago, Chile. President Hu's visit to Latin America reached goals of expanding consensus, enhancing mutual trust, exploring cooperation, and seeking common development (Ellis 2013). Four years later, in 2008, President $\mathrm{Hu}$ attended another APEC Summit, this time in Peru, and relations between China and Latin American countries have become better and deeper. Typically, China provides multibillion dollar loans, development aid, arms sales, and other beneficial economic agreements (Ellis 2013). Since then, one by one, most Latin American countries have moved their diplomatic relations from Taiwan to China. 
Just like another Latin American country, President Varela also established Panama-China diplomatic relations, eschewing Taiwan. In his speech on June 13, 2017, Varela said that since 2007, he had begun publicly proclaiming his position that Panama needed to establish diplomatic relations with China (Interview with President Juan Carlos Varela 2017), believing it the right path for Panama. Both Panama and China see a cooperative partner in mutual benefits and shared profits, especially in Panama Canal development. The Panama Canal is the most important sector in Panama, so its development is also important. China can overcome Panama's limitations in developing the Canal by providing development aid in very large quantities. For this to happen, Panama must follow the One China Policy, which states that the People's Republic of China (PRC) is the official government of Mainland China (including Tibet), Hong Kong, Macau, and Taiwan. All countries that agreed to establish diplomatic relations with the PRC must follow this policy and avoid official relations with Taiwan or else sever official relations with China (Jue 2006). Logically, Panama prefers China because Panama will gain greater benefits than in its relationship with Taiwan. As a nation-state, Panama must look to its national interest. Table I shows the significant differences between China and Taiwan's power.

Table 1. Comparison of China and Taiwan's Power (Source: Reprocessed from PRC \& ROC Country Profile)

\begin{tabular}{|l|l|l|}
\hline & China & Taiwan \\
\hline Population & Around 1.404 billion & $23,577,271$ \\
\hline Total area & $9,600,000 \mathrm{~km}^{2}$ & $35.801 \mathrm{~km}^{2}$ \\
\hline Total PPP & $\begin{array}{l}\$ 27.331 \text { trillion }(2019 \\
\text { estimate) }\end{array}$ & $\begin{array}{l}\text { \$1.306 trillion } \\
(2019 \text { estimate) }\end{array}$ \\
\hline Total GDP & $\begin{array}{l}\$ 14.216 \text { trillion (2019 } \\
\text { estimate) }\end{array}$ & $\begin{array}{l}\text { \$1.306 trillion } \\
(2019 \text { estimate) }\end{array}$ \\
\hline Military & $\begin{array}{l}2.3 \text { million active } \\
\text { personnel }\end{array}$ & $\begin{array}{l}275,000 \text { active } \\
\text { personnel }\end{array}$ \\
\hline $\begin{array}{l}\text { Military } \\
\text { budget }\end{array}$ & $\$ 151.5$ billion $(2017)$ & $\begin{array}{l}\text { \$10.6 billion } \\
(2017)\end{array}$ \\
\hline
\end{tabular}

China's as a rising power is certainly recognized worldwide--in its population, area, military, and economy. As the third largest country in the world, China has had the largest, most complex economy in the world for more than two thousand years, along with several periods of glory and decline. And since its heyday, China has become the fastest growing economy in the world. Data shows that in 2013, China became the second largest economy in the world based on total nominal GDP and PPP. China is also the largest exporter and importer in the world. From a military perspective, China's power increases annually, as indicated by the amount of spending on large military weapons and possession of nuclear weapons. China has the world's largest active army, and its military budget is the second highest in the world. After becoming a member of the United Nations (UN) in 1971, China became a permanent member of the UN Security Council, further increasing its international influence. In contrast, Taiwan's power is far from that of Mainland China. Taiwan still struggles against the One China Policy and for its sovereignty. From this perspective, Panama chose the right action for gaining a more beneficial friend.

Moreover, China's interest in Panama emerges from its second highest use of the Panama Canal, of which the Chinese have gained some economic control by investing in it. Instead, of expanding relations, especially economic cooperation, China could station military forces in Panama in the future. Additionally, China's One Belt One Road (OBOR) initiative finds Panama a very strategic location for expanding into the American region. Furthermore, the tension between China and the United States becomes more strained day by day. China's presence in Panama might affect US security, because of the possibility of China building a military base there. China's expanding relations with Latin America, including trade, loans, and investments, are powerful drivers of its increasing projection into the world economy. Indeed, for many of these states, expansion of economic ties with China has fueled expansion and reorientation of trade and physical infrastructure away from the United States and toward multiple global markets with heightened emphasis on the Asia-Pacific region (Ellis 2013). Overall, Chinese activities present immediate challenges to US national security interests, but the possibilities in the "rise of China" strengthen Panama-China relations.

Negotiations between Panama and China before Valera terminated official diplomatic relations with Taiwan were held in unofficial meetings. Panama's decision came after several years of private talks between Chinese and Panamanian leaders, possibly to preserve the sovereignty of nonintervention over an external country.

\subsection{Panamanian Domestic Consideration}

\subsubsection{The Importance of the Panama Canal}

At the domestic level, consideration of foreign policy goes inward. Creation of cooperation in diplomatic relations means that, as an important aspect, a country has the means to achieve its national interests. The Panama Canal becomes strategic, but why is the Canal so important to Panama and to the world? The Panama Canal is an artificial $82-\mathrm{km}$ waterway in Panama that connects the Atlantic Ocean with the Pacific Ocean. It also one of the most important sea gates in the world. Thus, the Canal is an important world trade area. Even in World War II, the Panama 
Canal Zone was vital for movement of American troops and military arms to Pacific War areas (Gerrald 2000).

The Panama Canal's 2018 annual report shows its contribution to the Panamanian National Treasury has grown $30 \%$ from 2016 to 2018 and, in 2018 alone, $8.5 \%$.
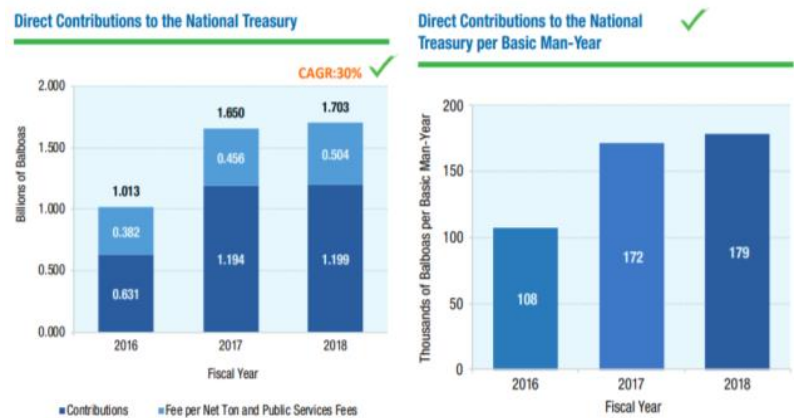

Figure 2 Panama Canal Contributions to National

Treasury (Source: Panama Canal annual report 2018)

*The balboa has been tied to the United States dollar (which is also legal tender in Panama) at an exchange rate of 1:1 since its introduction and has always circulated alongside dollars.

Direct contributions to the Panamanian National Treasury reached a record high of $\mathrm{B} / .1 .703$ billion, which is $\mathrm{B} / .44$ million above the estimated $\mathrm{B} / .1 .659$ billion for the fiscal year, and $\mathrm{B} / .53$ million or $3.2 \%$ more than fiscal year 2017. This figure includes surplus payments of $\mathrm{B} / .1 .199$ billion and per net ton and public services fees of B/.504 million. Moreover, direct contributions to the National Treasury for each basic man-years indicator increased B/.7,000 per basic manyear, 4\% more than in fiscal year 2017. This trend aligns with growth in direct contributions to the National Treasury and with higher productivity by basic man-year since inauguration of the Expanded Canal. This also comes with an indirect contribution to the National Treasury reaching $B / .223$ million. These contributions are mainly to social security, income tax, and education insurance. In addition, indirect contributions include goods and services from local suppliers and net salaries.

Data in Figure 3 show amounts of domestic income. The Canal's global importance encourages the Panamanian government to maximize its economic profits. Furthermore, the Chinese government wants to fund construction for developing the Canal. In December 2017, the same year Panama and China established diplomatic relations, Beijing funded construction of a new $\$ 1.4$ billion bridge spanning the Canal.

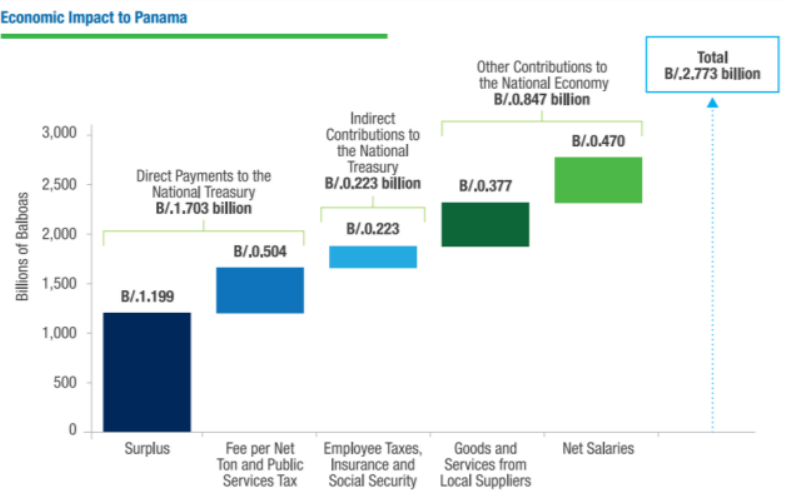

Figure 3 Panama Canal: Economic Impact on Panama (Source: Panama Canal annual report 2018)

\subsubsection{Sovereignty of Panama}

Historically, the United States has long been involved in Panama, taking control of the Canal property in 1904 and constructing the Canal from 1904 to 1914. After many years of US control, Panamanians protested on the basis of Panama's sovereignty. On January 9, 1964, anti-American riots over the Panama Canal Zone's sovereignty started after a Panamanian flag was torn and Panamanian students were killed during a conflict with Canal Zone Police officers and residents. This is also known as the Flag Incident or Flag (Meditz \& Hanratty 1989) and considered a significant factor in the US decision to transfer control of the Canal Zone to Panama through the 1977 TorrijosCarter Treaties. Panamanians believed that the Canal Zone rightfully belonged to Panama. Furthermore, relations between Panama and the United States became increasingly tense. In mid-December 1989 and late January 1990, the United States invaded Panama, in Operation Just Cause. During the invasion, 516 Panamanians were killed. With the rise of Panamanian nationalism in the mid-20th century, a critical approach toward US interventions in local political life became a vehicle for negotiating a Panamanian national identity (LaFeber in McPherson 2003). The tension finally found its melting point. On September 7, 1977, a treaty was signed by President Jimmy Carter of the United States and Omar Torrijos. This treaty provided free control of Panama and guaranteed the Canal's permanent neutrality. The treaty led to full Panamanian control, effective at noon on December 31, 1999, when the Panama Canal Authority (ACP) assumed command of the waterway.

Due to this historical background, tension between Panama and the United States still exists. Many and various studies have explored ongoing Panamanian sentiment. Research into middle-class Panamanian society's perception of the United States found that many Panamanians see US citizens as "person[s] who came to Panama with lots of money to rest or invest" or "person[s] who always think of [their] own interests" 
(Theodossopoulos 2010). Besides that, many Panamanians also see US citizens positively, as openminded, pleasant, and friendly. However, these positive perceptions often come along with the word "but," For example, "they are very intelligent, but they are selfish," or "... but they have faults." Most commonly, Panamanians criticize US citizens' arrogance. Panamanian respondents explained that there are advantages and disadvantages in Panama-US relations.

Not only Panama but other Latin American countries harbor anti-US sentiment. Alan McPherson (2006) believes that the more significant and frequent US intervention, "the more widespread, deep and visceral anti-U.S. sentiment became." McPherson argues that historical memories and national mythologies have shaped these views. Panama even has an anti-American holiday, January $9^{\text {th }}$, Martyrs' Day, commemorating the outbreak of violence between Panama and the United States in 1964.

\subsubsection{Security by Region ( $L A C \& U S$ )}

Lying in the Latin America Caribbean (LAC) region, close to the US superpower state, Panama requires adequate security. Panama's geography, clearly advantageous, allows it to be the hub of the Americas, a central logistics point with the Canal, but its location also requires great enforcement to maintain its sovereignty. The main goal of the Panamanian Minister of Security is to make Panama the most secure country in America--not just in Latin America, but in the Americas (Bethancourt 2017).

That future Panama-China relations will include military alliance is not impossible. Given Panamanian-US history and tension between the United States and China, a military alliance is likely. If such an agreement emerges, the United States will react quickly, facing a security dilemma in that the distance between China and the United States is narrowing. But, what about Panama? Most likely, the historical story will cause Panama to prefer China, given that China has provided more benefits for Panama.

Since the treaty with China was signed, Panama needs to continue its sovereignty and avoid repeated external interventions. As for policy termination of diplomatic relations with Taiwan and establishment of official diplomatic relations with China in 2017, Panama did not communicate the policy to the United States beforehand. Although regrettable to the United States, Panama's president asks for international respect for determining its present and future policies.

\subsection{Win-Set}

China and Panama have successfully done business together for decades without having official ties. Negotiations between China and Panama were not well known to the public until President Varela officially announced diplomatic relations with China immediately after the unilateral termination of Panama's diplomatic relations with Taiwan. In this case, the Panamanians and the Chinese did not practice transparency of negotiations for transition of diplomatic relations with Taiwan to China. This might have avoided external intervention in Panama's decision. In line with the theory of two-level games, that negotiators might be heads of government representing nations, Panamanian President Varela can be said to have been the main negotiator of the relationship between Panama and China.

However, we could have predicted the possibility of this foreign policy (or what in this theory is called a win-set). Based on Robert Putnam's theory of two-level games, three important factors can determine the winset: 1) the win-set's size depends on the distribution of power, preferences, and possible coalitions among Level II (domestic actors) constituents. This can be seen in China's contribution to Panama's national interest, which certainly strengthens Panama, especially its economy. By formally establishing diplomatic relations with China, Panama can increase its power, to build commercial and strategic positions in the Western Hemisphere. Not only the government approved this policy, but other Panamanian domestic actors, such as businesses and the public, also benefited and automatically supported the policy. For example, for the China-Panama FTA, Panama can benefit from its growing role as a regional logistics hub, build its exports to China, and protect local farmers. According to Putnam's theory of win-set, the greater the domestic agreement, the greater the win-set and the greater the negotiations at the first level in achieving success. 2) The win-set's size depends on Level II political institutions. President Varela said that before he became president, he realized that Panama needed official diplomatic relations with China. In 2010, when Varela visited China for the Special Olympics, he said that once he became president, he would recognize the One China Policy (Interview with President Juan Carlos Varela 2017). Clearly, the Panamanian government was ready to switch diplomatic ties. Doing so also preserved Panama's sovereignty, preventing US intervention, which has historically hurt Panamanians. In addition, the relationship with China bestows Panama with influence in the LAC region, not only by strengthening the country, but by enabling it to help its neighbors with regional stability through dialog. With further construction of the Canal, Panama can play a significant role in helping the business community in the LAC. 3) 
The win-set size depends on the strategies of Level I (international actors) negotiators. As mentioned, China's strategy, especially in development aid and investment, has a major impact on policies implemented by Panama. With the One China Policy urging countries to choose China or Taiwan, clearly, benefits Panama gained by switching to China will be greater than remaining with Taiwan even though the relationship had been established for more than 100 years.

The three factors above illustrate the size of the winset. As a sum of the two levels, Panama chose to establish diplomatic relations with China. On the other hand, Panama needed to recognize the One China Policy by severing its diplomatic relations with Taiwan. The good relations that existed with Taiwan for more than 100 years ended in Taiwan's disappointment. And this foreign policy consideration is a step considered a winwin for both Panama and China.

\section{PANAMA-CHINA IN THE PANAMA CANAL ZONE}

Relations between Panama and China has grown very fast. China's direct investment in Panama has exceeded US \$230 million. China contracted projects worth US $\$ 1.33$ billion by the end of 2017 . Nearly 30 Chinese companies are running marine shipping, telecommunications, financial, and infrastructure businesses in Panama with local partners, thus creating jobs for local people. China is the second largest user of the Panama Canal with over 1,000 ships passing through the Canal every year.

After establishing diplomatic relations, Panama and China signed an agreement. On December 6, 2018, the government of Panama awarded a US \$1.4 billion contract to a Chinese consortium to initiate a new infrastructure project on the Panama Canal (Martinez 2018). The winning group is Panama Cuarto Puente, the consortium, which outbid similar offers from Spanish, Italian, and South Korean companies; it is composed of the China Communications Construction Company and the China Harbour Engineering Company (CHEC) (ABS-CBN). The new contract allows the Chinese consortium to begin construction of a massive bridge over the Panama Canal, connecting Panama City to its western suburbs. This deal makes Panama the first Latin American country to join China's OBOR infrastructure development initiative, which is responsible for creation of several land and sea travel routes throughout Southeast Asia and East Africa. Besides that, China has increased its own use of and investment in the Canal in recent years. Before ties were established in 2016, a Chinese group bought the largest port on the Panama Canal, and various Chinese firms are actively working to expand the Canal's facilities ( $\mathrm{ABC}$ ). Container ports and cruise ship ports constructed by China on both the
Pacific and Atlantic shores were built beforehand through this agreement, as were the bridge over the Panama Canal, two natural gas power plants, and certain investments in the Panama free trade zone, which is increasingly dominated by Chinese companies.

At this time, Panama's Canal Authority still controls the Canal. China's direct involvement in controlling the Canal is not yet in evidence, but development aid and other agreements between Panama and China have already begun. Thus, that China will someday, at least partially, control the Canal is not impossible.

\section{CONCLUSION}

The logic of Robert Putnam's two-level games theory explained Panama's diplomatic relations termination of Taiwan in 2017. From level I (international), China succeeded in winning negotiations with Panama, with its big strategy of investment, trade, and development aid. With China's presence, Panamanians believe they can achieve their national interests. Despite the disappointment of the United States at China's relations in Latin America, this winwin mutually benefited both China and Panama. Likewise, at Level II (domestically), Panama sought to maximize economic profit with its second biggest user. A historical side of anti-Americanism in Panama and the Latin American Caribbean demanded that Panama retain its sovereignty. Thus, having geological proximity with LAC and a superpower state like the United States, Panama believes that it requires great security. "The rise of China" might form Panama's future military alliance. Too, consideration at the domestic level matched that at the international level. This means that the greater the domestic agreement, the greater the win-set and the greater the negotiations at the first level in achieving success. Domestic agreement pushed Panama to follow the One China Policy, so that termination of relations with Taiwan occurred. Finally, negotiations between Panama and China seem greater day by day.

\section{REFERENCES}

[1] Americas Now interview with President Juan Carlos Varela. (2017, October 14). Retrieved from https://www.youtube.com/watch?v=tLU1Qkgi2j8

[2] DIALOGO Digital Military Magazine exclusive interview with Panamanian Minister of Security Alexis Bethancourt. (2017, February 22). Retrieved from https://dialogoamericas.com/en/articles/panama-be-most-securecountry-americas

[3] Ellis, RE 2013, 'The Strategic Dimension of Chinese Engagement in Latin America', William J. 
Perry Center for Hemispheric Defense Studies, Perry Paper Series, vol. 1, no. 1.

[4] Esteban, M 2008, 'The Diplomatic Battle Between Beijing and Taipei in Latin America and The Caribbean', Revista CIDOB d'Afers Internacionals, No. 81(209-231), 8.

[5] Flurry, G 2000, 'The Rise and Falls of a Superpower', Retrieved from https://www.thetrumpet.com/221-the-rise-and-fallof-a-superpower

[6] Huang, Kwei-Bo on Schubert, Gunter. (2016). Routledge Handbook of Contemporary Taiwan. New York: Routledge, 470.

[7] Jue, S 2006, 'The "One China" Policy: Terms of Art', American Journal of Chinese Studies, vol. 13 no. 1, pp. 79-88. Retrieved from http://www.jstor.org/stable/44288816

[8] Martinez, K 2018, "Symbolic power shift as China signs \$1.4 billion contract with Panama Panoramas Scholarly Platform", Retrieved from https://www.panoramas.pitt.edu/news-andpolitics/symbolic-power-shift-china-signs-14billion-contract-panama

[9] Mcpherson, A 2006, Anti-Americanism in Latin America and the Caribbean. Berghahn Books, New York, 271.

[10] Meditz, SW, Hanratty, DM \& Library Of Congress. Federal Research Division. (1989) Panama: A Country Study. Washington, D.C.: Federal Research Division, Library of Congress. Retrieved from the Library of Congress, https://www.loc.gov/item/88600486/
[11] Ministry of Diplomacy Coordination Council (2017, June 13). The ROC government has terminated diplomatic relations with Panama with immediate effect to uphold national dignity. Retrieved from https://www.mofa.gov.tw/en/News_Content.aspx? $\mathrm{n}=1 \mathrm{EADDCFD} 4 \mathrm{C} 6 \mathrm{EC} 567 \& \mathrm{~s}=\mathrm{CF} 11 \mathrm{CEBE} 98 \mathrm{E} 465$ 73

[12] Panama Canal Annual Report 2018. (2018). Retreived from https://www.pancanal.com/eng/general/reporteanual/2018-AnnualReport.pdf

[13] PRC Country Profile. Retrieved from https://www.nationsonline.org/oneworld/china.htm

[14] Putnam, R 1988, 'Diplomacy and Domestic Politics: The Logic of Two-Level Games', International Organization, vol. 42, no. 3, pp. 427 60.

[15] ROC Country Profile. Retrieved from https://www.nationsonline.org/oneworld/taiwan.ht $\mathrm{m}$

[16] Theodossopoulos, D 2010, 'With or Without Gringos; When Panamanians Talk about the United Statesand Its Citizens', Social Analysis, vol. 54, no. 1, Spring 2010, pp. 52-70. Berghahn Journals. doi:10.3167/sa.2010.540104

[17] Wadrianto, GK 2017, Tinggalkan Taiwan, Panama Resmi Buka Hubungan Diplomatik dengan ChinaKompas news. Retrieved from https://internasional.kompas.com/read/2017/06/13/ 11342011/tinggalkan.taiwan.panama.resmi.buka.hu bungan.diplomatik.dengan.china?page $=2$ 